\title{
An Exploratory Study of English Teachers: The Use of Social Media for Teaching English on Distance Learning
}

\author{
Ubaedillah $^{1}$, Damar Isti Pratiwi' ${ }^{2}$ S. Thoriqul Huda3 ${ }^{\text {, Dwi Agung Kurniawan4 }}$ \\ ${ }^{1}$ Universitas Muhadi Setiabudi, e-mail: ubaedillah2@gmail.com \\ ${ }^{2}$ Politeknik Perkeretaapian Indonesia, e-mail:damar@ppi.ac.id \\ 3Universitas Selamat Sri, e-mail: s.thoriqulhudaunissbatang@gmail.com \\ 4STIE Assholeh Pemalang, e-mail:dwiagungkurniawanog9@gmail.com
}

\begin{tabular}{|c|c|}
\hline ARTICLE INFO & ABSTRACT \\
\hline $\begin{array}{l}\text { DOI: } \\
\text { http://dx.doi.org/10.21093 } \\
\text { /ijeltal.v5i2.753 }\end{array}$ & $\begin{array}{l}\text { This study was conducted to determine how English teachers used social } \\
\text { media to teach English. An exploratory study was used in this study to look } \\
\text { into a detailed and in-depth analysis of the use of social media in English } \\
\text { language learning by Cirebon junior high school teachers. This study used } \\
\text { purposive sampling from } 43 \text { English teachers at Cirebon junior high schools. } \\
\text { Ten teachers (five male and five female) have been chosen. In about } 20 \text { to } 30 \\
\text { minutes, each participant was asked the questions. The researcher recorded } \\
\text { all of the conversations during the interview session as part of the data } \\
\text { collection process. Whatsapp, Facebook, Instagram, Tiktok, and YouTube are } \\
\text { the most popular social media platforms with strong categorized. Whatsapp } \\
\text { has a higherpresentation value than other social media types. There were five } \\
\text { themes identified as a result of the interview session of the teacher's } \\
\text { perceptions of social media used on distance Learning; 1) Kinds of social } \\
\text { media, 2) Activities, 3) Motivation, 4) Improving students English language } \\
\text { skills, and 5) Effectiveness. }\end{array}$ \\
\hline \multicolumn{2}{|c|}{$\begin{array}{l}\text { How to cite: } \\
\text { Ubaedillah, U., Pratiwi, D.I., Huda, S.T., Kurniawan, D.A. (2021). An Exploratory Study of English } \\
\text { Teachers: The Use of Social Media for Teaching English on Distance Learning. Indonesian Journal of } \\
\text { English Language Teaching and Applied Linguistics, 5(2), 361-372 }\end{array}$} \\
\hline
\end{tabular}

\section{Introduction}

The COVID-19 pandemic forced schools all over the world to quickly shift to online teaching. This unplanned and unprecedented disruption to society and education changed teachers' work in Indonesia and elsewhere (Atmojo \& Nugroho, 2020). Coronavirus disease 2019 (COVID-19), which originated in the People's Republic of China's Hubei Province, has spread worldwide. This virus has infected a large number of countries. The WHO Emergency Committee declared a global health emergency in late January 2020, citing an increase in COVID-19 confirmed cases worldwide (McAleer, 2020; Velavan \& Meyer, 2020).COVID-19 cases among HCWs from 52 countries were reported to the WHO on April 8, 2020. However, because there is no systematic reporting of HCW COVID-19 infections to WHO, this number 
likely underestimates the incredible number of COVID-19 HCW infections worldwide. In Indonesia, the number of confirmed COVID-19 cases has surpassed 1.500 (Culp, 2020). It is so dangerous that the government has banned all face-to-face teaching and learning activities. All schools and educational institutions were closed, and distance learning was implemented as part of the government's effort to prevent the dangerous coronavirus spread. For COVID19-affected areas, the Republic of Indonesia's Ministry of Education and Culture has ordered schools to implement online learning from March 17, 2020 (Mendikbud, 2020). Running online learning has become a modern obstacle for both teachers and students (Atmojo \& Nugroho, 2020).

The implementation of online and distance learning is becoming more popular. According to others, it has soon become the preferred or 'modern standard' form of research worldwide. Surprisingly little is learned about what happens to first-year distance students when they enrol in tertiary institutions, what motivates them, and how they handle the transition to formal distance learning. (Brown et al., 2015). Teachers had to rapidly define, adapt, and incorporate digital instructional practices that were versatile and fulfilled students' needs due to this paradigm change. Even though digital learning and teaching are well known, many teachers were faced with learning new technology for e-learning and m-learning (mobile) when using (Budianto \& Arifani, 2021). A variety of advantages are available in an online teaching environment, including the ability to study anywhere at any time, having more time to think and respond, and increased learning flexibility (Lee \& Bailey, 2020).

Social media is a type of media distributed through various electronic and rechargeable devices such as cell phones, computers, tablets, and various other devices to help people share their ideas with others simply and systematically. It is primarily used for global communication and awareness (Andreas, 2010). The pandemic ushered in an immediate "new normal" in which administration, teachers, and students may not have had access to an e-learning platform (Budianto \& Arifani, 2021). The online world has changed dramatically in the last ten years (Wang et al., 2011). Many students spend countless hours on social media sites like Facebook, YouTube, Instagram, WhatsApp, Twitter, and others every day. There are numerous types of social media, including. Even today, YouTube is Indonesia's most popular social media platform. Language is primarily a means of communication and is used in almost every aspect of life. It is a language used to transmit and communicate information among friends, family members, coworkers, and the teaching-learning process (Khan et al., 2016). Teachers and researchers have been using new and exciting digital technologies for second and foreign language learning in recent years, including mobile technologies, gaming, and social media, to name a few (Xodabande, 2017).

In EFL, social media use offers specific opportunities for students to improve their English language skills. English is indeed one of the most widely used languages on social media since English is considered a foreign language used to communicate worldwide. People in Indonesia, primarily students, use English as a foreign language, with English being taught and learned in only a few places such as schools, classes, or universities as one of the subjects offered there. English is a language that is used to Learners connect using their cell phones and social media, and they claim that mobile learning would allow them to learn anytime and at any time (Novawan et al., 2020). 
Much prior research explored the phenomenon of introducing schooling in the aftermath of the Covid-19 pandemic in Indonesia. (Ariyanti, 2020) found that the students face three major types of challenges like internet access, safe cause, and the use of such online application. (Sugianto \& Ulfah, 2020) unravel the teachers' expertise and the difficulties and prospects of intercultural language education throughout the present scenario. The teachers' intercultural expertise was considered mild.

Furthermore, some difficulties observed comprised the facets of internet access and students' psychological component, such as attitudes toward intercultural language teaching and learning performed in an online classroom. (Astia \& Yunianti, 2020) investigate the form of adjectives in the most used adjectives and the adjective functions on scholarly writing about COVID-19.

(Sari, 2020) explore the students' expectations of their participation in the online learning process. It also explores the influential learners' positions in the online learning community and the potential reasons impacting their involvement or participation in the online learning process. (Pustika, 2020) investigate the future English teachers' outlook on the introduction of e-learning in the Covid-19 pandemic period. (Fauzan \& Nadia, 2005) investigate the introduction of internet-based learning of Madrasah Aliyah (MA) in Kalimantan and the barriers they face in making innovation and integration towards internet-based learning, particularly in English classrooms.

According to the data, teachers are more engaged in discussion when using social media than traditional textbooks. As a result, this study looked into how English teachers at Cirebon used social media to teach English, broken down into two research questions: 1) what types of social media do teachers most commonly use when teaching English? 2) what are the teacher's thoughts on using social media in the classroom?

\section{Literature Review}

\subsection{Social Media for Education}

Social Media for Education Social networking has affected how content can be transmitted in teaching and learning and how individuals exchange ideas, resources, and news, cooperating and collaborating. (Alshabeb \& Almarqrn, 2018) clarifies what the difference between cooperating and collaborate precisely is as follows: "can achieve cooperation if all parties do their allocated parts separately and bring their findings to the table; teamwork, in comparison, means direct cooperation among individuals to deliver a product and entails compromises, consultations, and accommodating others' viewpoints." Both methods of working can encourage by using social media as, according to (Hamat \& Hassan, 2019) provide a way for people to "share concepts, content, feelings, and relationships online."

The highlights were the potential for incorporating social media practice into education. The best known social media networks shared throughout many countries worldwide are their initial launch dates, Facebook, Twitter, Instagram, and Snapchat. Over the past ten years, the amount of research exploring social media use for educational purposes has mushroomed (Ambarwati et al., 2019). Social media is used in education for both formal and informal learning. Most young people will already be aware of using social media for communication or maybe skilful at texting and gaming. Still, some have already grasped the potential social media presents for learning. 
During the past ten years, personal efforts have made by the worldwide community of mobile learners to improve, deepen and extend this topic in several diverse ways. Nowadays, it can easily integrate the learners' needs into most mobile learning programs due to their innovative features and flexibility in their processes. During their field activities in real-time, a large amount of data can now quickly processed by learners, and they can keep track of unfolding developments at the same time. In the past, researchers would need to initially gather data and later process this, making use of a specially designed set-up (Veda et al., 2016).

Here some media social can be used by the teachers;

\section{1). Facebook}

Facebook users have personal websites called "Profiles," which they build using simple menus. Users will restrict access to their Facebook profiles by adjusting their account's privacy settings. "Friend" status normally provides unrestricted access to a person's profile, including the ability to view and comment on all of the photos in that person's galleries. To hook up, one can send "Friend Requests" to other Facebook users and allow friend requests from others, allowing them to see each other's profiles and write on each other's "Walls," which are interactive blogs about their activities with feedback from others. Links, photos, animations, and interactive objects or gifts are often displayed on these walls. Events and parties may also have their site (Wankel, 2009).

Facebook is one of the most widely used social media sites. Mark Zuckerberg founded it, intending to bring people from various backgrounds together and encourage participation. People use Facebook to stay in contact with one another. They communicate with their families, friends, and colleges without wasting much time. "People from collectivistic societies use social network platforms to establish close relationships with a limited number of links rather than establishing new interactions with people". (Ambarwati et al., 2019). The majority of Facebook users are women, which is a fascinating aspect of the phenomenon.

\section{2). Blogs}

A blog is a compilation of writing and photographs that is self-published and accessible through the internet (Veda et al., 2016). A "blog," also known as an "internet log, journal, or chronicle," is a web-based log, newspaper, or chronicle produced by an author or group with ongoing reports that include diary-style commentary, often with criticism of and links to online publications and related news. Blogs can be an excellent way for students and professors in a course to exchange content. The teacher could start a blog to track the course's progress, session by session. L earners and others (assuming this is publicly posted on the web) would be able to view PowerPoint presentations, lecture notes, transcripts of lectures or class sessions, and other materials (Ambarwati et al., 2019). The emphasis, complexity of subjects, and prominence of blogs all vary significantly. Daily announcements, exchanges of comments, and brief blogs are all part of the blogging tradition. Learners will express themselves in a new language using blogs, which is an exciting forum.

\section{3). Youtube}

The use of video is increasing in many areas of society, including higher education, as we enter the second decade of the twenty-first century. It is aided by new pocket-sized camcorders from Flip Creative Labs, Kodak, Sony, Sanyo, Samsung, and others, which 
feature one-touch digital zoom and high definition resolution (Wankel, 2009). YouTube is a vast source of instructional material and one of the most popular websites on the internet. Over ten million instructional videos are available on the web, many of which have been uploaded by colleagues (Veda et al., 2016).

\section{4). Twitter}

Twitter, the most well-known free microblogging programme, is useful for quick exchanges of information, knowledge, and opinions (Wankel, 2009). The instructor will configure their account so that only the classes they need to see important tweets, such as individual lessons, access them. Some professors invite students to tweet during class sessions to involve and excite them about the session's discussions and topics (Veda et al., 2016).

\section{5). WhatsApp}

WhatsApp is a free messaging app that runs on several smartphones, including iPhones and Android phones, and undergraduate students typically use it to exchange visual messages such as photos, videos, and audios, as well as plain text messages. Because WhatsApp needs internet access, a tremendous amount of knowledge can be obtained in real-time, and sharing information through technology is instantaneous and easy (Gon \& Rawekar, 2017).

\section{6.) Other applications}

Mobile devices' features can provide users with a high degree of freedom while still serving as a link to the rest of society. This is attributed to the user's desire to check for information on the internet or smartphone applications such as dictionaries, grammar, and spelling software. Document translation resources, such as Google Translate, encyclopedias, such as Wikipedia, etc. The trip (Veda et al., 2016).

\subsection{Purposes of Distance Learning}

Distance learning is schooling, and its possible aims are derived from those of education. These priorities are now more troubled than they have ever been (Traxler, 2018). One aim of education is to service economies and put people to work, especially in cash economies and paying employment. This has achieved mainstream recognition. However, it is becoming more troublesome. Not only has globalization made jobs a competitive phenomenon over the past two decades as businesses chase shifting economies, capital, raw materials, tax, and tariff regimes, but there is increasing talk of the hollowing out of the labour market (Mclntosh, 2013).

During our lifetimes, emerging innovations have been triggers of these phenomena, and artificial intelligence (Al) and the Internet of Things (IoT) will only exacerbate these processes shortly. These aspects will be explored more in our discussion of educational technology developments. (Traxler, 2018) English becomes a school subject and is expected to study in a global context. Possess a bargain in terms of work. It happens because a high degree of unemployment and English proficiency are strongly regarded in the workplace, industry, and tourism. It shows to people the financial advantages of learning English (Atmojo \& Nugroho, 2020). 


\section{Research Methodology}

This study used a survey as a research design, and an exploratory study was used in this study to look into a detailed and in-depth analysis of the use of social media in English learning Survey research was conducted by distributing questionnaires using google Forms. The primary data collection of this research is by distributing questionnaires to respondents (Creswell, 2014).

\subsection{Participants}

To find the participants, the researcher used purposive sampling. It means that the researcher chooses participants because they can help the researcher better understand the research questions (Creswell, 2014). A total of 43 English teachers from Cirebon junior high schools participated in this study and completed the questionnaire. The researcher chose ten teachers (five male and five female) to participate in the semi-structured interview.

\subsection{Instruments}

Simultaneously, data is collected via Google form questions that are distributed via WhatsApp. Teachers were asked to fill out a questionnaire about their use of social media and their perceptions of using social media for e-learning in distance learning. This section of the interview included some questions, including five questions about the types of social media most commonly used in teaching English and six questions about the use of social media in teaching English. In about 20 to 30 minutes, each participant was asked the questions. The researcher recorded all of the conversations during the interview session as part of the data collection process. The interview protocol was created as a follow-up to the questionnaire, which delved deeper into respondents' social media use. Besides, those who took part in the interview session answered the following questions:

1. What social media platforms do you use?

2. What social media platforms do you primarily use when teaching English?

3. When do you usually use social media in your English classes?

4. How frequently do you use social media in your English classes?

5. What are the drawbacks of using social media in English classes?

6. What are the benefits of using social media in English classes?

8. Who advised you to use social media in your English classes?

9. How can social media assist you in your English teaching?

10. How can social media influence your English teaching?

11. What is the efficacy of using social media in English teaching?

\subsection{Data Analysis Procedures}

Exploratory research was used in this study to look at a systematic and in-depth review of the use of social media in English language learning by Cirebon junior high school teachers. The findings of the survey were interpreted using statistical statistics such as frequency and percentage. The findings of the interview were interpreted using phenomenological case analysis and thematic labelling. 


\section{Findings}

\subsection{Types of social media that commonly used by English teachers}

The researcher organized data analysis results from a survey about social media use by teachers in learning English. According to the findings, Whatsapp is one of the most commonly used social media platforms by English teachers. The table below demonstrates this;

Table 1 The most popular social media used by English teachers.

\begin{tabular}{c|l|c}
\hline No. & Types of social media & Percentage \\
\hline 1. & Youtube & $15 \%$ \\
\hline 2. & Facebook & $12 \%$ \\
\hline 3. & Instagram & $13 \%$ \\
\hline 4. & Twitter & $2 \%$ \\
\hline 5. & Whatsapp & $37 \%$ \\
\hline 6. & Telegram & $\mathbf{2} \%$ \\
\hline 7. & Email & $\mathbf{1} \%$ \\
\hline 8. & Tiktok & $15 \%$ \\
\hline & Total & $\mathbf{1 0 0} \%$ \\
\hline
\end{tabular}

The research finding of table 1 shows that there are eight types of social media commonly used by junior high school English teachers in Cirebon as respondents in this study. Many respondents use the Whatsapp social media type as the first rank of English learning media with $37 \%$. In the second rank, the type of social media that respondents often use is Youtube, which is currently becoming a popular platform for Indonesia of all ages, 15\%. In contrast, Tiktok ranks third most used by respondents to distance learning English with the same number of percentages, namely $15 \%$, even though this is a new Indonesia platform. Still, many social media users also use it as a means of learning and teaching English. In fourth place, respondents often use Instagram to learn English with distance learning. It can prove that $13 \%$ of English teachers in Cirebon use social media Instagram as a teaching medium. The fifth rank was Facebook as much as $12 \%$. However, this is included in the category of social media that people in Indonesia have long used, but this is very effective in learning English. Many Facebook groups as a medium for learning English can communicate with the many people who joined the group. Both Twitter and Telegram social media got $2 \%$, which means that respondents do not use social media too often as a teaching tool. Moreover, the last one is Email, where delivery such as digital correspondence and sending files and short messages to students got $1 \%$.

From the results of this study, it can conclude that WhatsApp is the most preferred choice. It is possible because apart from social media in learning English, almost all Indonesian people use WhatsApp to communicate daily. In addition to the data in Table 1 above, the results of research on the types of social media commonly used by English teachers can be illustrated in Figure 1 below; 


\section{Types of social media that mostly used by English teachers}

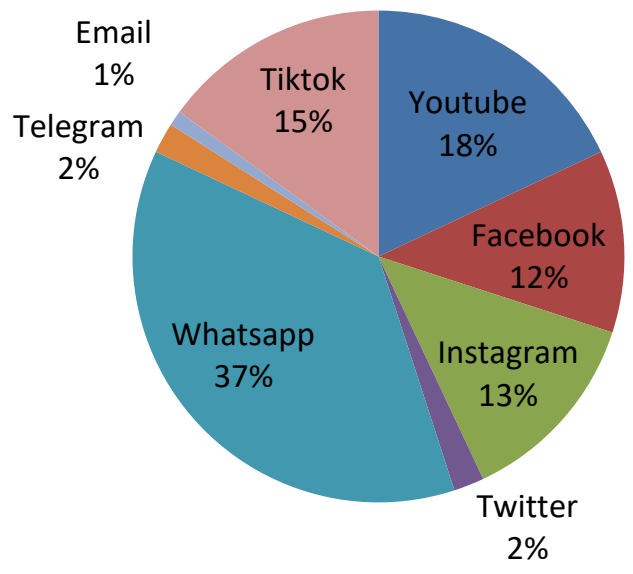

Figure 1. Types of social media that commonly used by English teachers

\subsection{The teacher's perceptions of social media used on distance Learning}

The researcher focused the analysis and discussion on teachers' perceptions and the context in which they saw the benefits of using social media to teach English. The table below depicted some of the major themes and sub-themes.

Table 2. Theme and Sub-theme of the research questions

\begin{tabular}{lll}
\hline No. & \multicolumn{1}{c}{ Themes } & \multicolumn{1}{c}{ Sub- Theme } \\
\hline 1. & Kinds of social media & $\begin{array}{l}\text { Youtube, Facebook, Instagram, } \\
\text { Twitter, Whatsapp, Telegram, } \\
\text { Email, Tiktok }\end{array}$ \\
\hline 2. & Activities & Discussion, Quiz \\
\hline 3. & Motivation & Self-confidence, Interesting \\
\hline 4. & Improving Students & $\begin{array}{l}\text { Improving students' Listening, } \\
\text { English Skills }\end{array}$ \\
& & Speaking, Reading, Vocabulary, \\
& & Pronunciation, grammar skills \\
\hline 5. & Effectiveness & Easy to use, easy to understand \\
\hline
\end{tabular}

There are ten participants in this study, five female and five male respondents. A pseudonym was assigned to each of the respondents. $T_{1}, T_{2}, T_{3}, T_{4}, T_{5}, T 6, T 7, T 8, T 9$, and $T_{10}$ were the number of teachers.

Several types of social media emerged due to the respondents' use of social media to teach English. Whatsapp, Youtube, Facebook, Tiktok, and Instagram are four examples of social media applications that teachers commonly use. During the interview, respondents said things like;

"I have some social media like WhatsApp, Youtube, Tiktok, and Instagram." However, I advise my students to join an English learning forum on Facebook". (T3) 
Participants in the activities category stated that they always use social media to facilitate discussion and communication when teaching English. According to the findings, all participants frequently converse and communicate with one another in English. For example, one of the participants, T7, stated,

"I always discuss the English language with my students, give the assignment or task using social media." (T7)

Teachers mentioned being self-directed and interested in teaching English using social media in the motivation category. As one teacher put it,

"I can share my material, quizzes, and even tasks" using social media. Furthermore, the lesson piqued my students' interest". (T2)

The fourth category was improving students' English skills through various media social tools such as Whatsapp, Facebook, Instagram, and YouTube, as defined by English teachers. These tools offer some advantages in terms of assisting students in improving their English skills.

"As a teacher, my students and I use social media daily. They can use them to practice reading, speaking, and listening in English easily". (T5)

The final category was effectiveness, which was defined as an English teacher's ability to communicate effectively through various social media forms. It has some advantages in assisting students in comprehending English learning materials and making distance learning English language learning more effective. For example, one teacher stated,

"I believe that social media assists me in teaching English more effectively." Because social media provides some options for me to teach English via distance learning easily. (Tg)

\section{Discussion}

The teachers' experience was a willingness among teachers to incorporate social media into many studies (Guy, 2012). The use of social media provides students with some opportunities to practice their English. Students were able to improve their critical thinking skills by using social media. The majority of participants stated that using social media allowed them to practice their English skills because they could engage in oral and written communication. Social media can then be seen in various classroom activities, as it is well known that learning through social media can improve students' knowledge, particularly in learning English (Zam Zam Al Arif, 2019). Teachers must be appropriately trained and equipped with sufficient knowledge and skills to maximize their online learning use (Atmojo \& Nugroho, 2020). However, some may argue that teachers are not always as skilled as students in using technology in the classroom and that some are unwilling to do so (Hamadeh, 2020). Social media enable social interaction, collaboration, and deliberation among multiple stakeholders (Guy, 2012). It enables students to acquire critical knowledge and social skills and become active citizens who create and share content (Wang et al., 2011).In both formal and informal learning, social media is now being used in education. Most young people are familiar with using social media for communication and may be adept at texting and gaming, but some have already recognized social media's educational potential (Alshabeb \& Almarqrn, 2018).

The previous study (Ariyanti, 2020; Astia \& Yunianti, 2020; Fauzan \& Nadia, 2005; Pustika, 2020; Sari, 2020; Sugianto \& Ulfah, 2020) concentrated exclusively on the phenomenon of the education process during the Covid-19 pandemic. The purpose of the research dressed 
the broader use and focused on college research, which was different from this research, which only focused on secondary school education and social media for teaching English in distance learning. The results of this study can be used as evaluation material for online class learning. Social media is another well-known thing that is used by people of all ages and educational levels. On the one hand, the positive aspect of online communities is that youths can utilize them for academic assistance and support. On the other hand, the students use electronic media while studying or doing homework (Wang et al., 2011).

There were five themes identified as a result of the interview session. 1) Kinds of social media, teachers use various social media types to help students learn English, including Youtube, Facebook, Instagram, Twitter, Whatsapp, Telegram, Email, and Tiktok. 2) Activities for using social media in English teaching, with sub-themes of Discussion and Quiz. 3) Motivation. Students' motivation can be improved through social media, with the subthemes of selfconfidence and interest. 4) Improving students' English language skills, Improving students' English skills through social media with sub-themes. Students' listening, speaking, reading, vocabulary, pronunciation, and grammar skills are all improved. 5) Effectiveness, social media use can make ELT more effective, easy to use, and understand.

\section{Conclusion}

Teachers use social media when Indonesia prevents face-to-face learning in the classroom and forces distance learning. English teachers have become media users, with e-learning and facilities for junior high school teachers limiting their options. Whatsapp, Facebook, Instagram, Tiktok, and YouTube are the most popular social media platforms with a strong presentation. Even though teachers use all of these social media types daily, Whatsapp has a higher presentation value than the other social media types. During the Indonesian pandemic of covid-19, the teachers used e-learning on distance learning as a social media user. This research can be expanded upon in future studies with a more narrow focus or used to advance the world of knowledge in general.

\section{References}

Alshabeb, \& Almarqrn. (2018). A Study of EFL Saudi Students' Use of Mobile Social Media Applications for Learning. Arab World English Journal (AWEJ), 53(4), 214-226. https://doi.org/https://dx.doi.org/10.24093/awej/call4.17

Ambarwati, R., Nurkamto, J., \& Santosa, R. (2019). Phatic and Politeness on Women's Communication in Facebook Humanistic Teaching Perspective of Being Polite in Social Media. Indonesian Journal of English Language Teaching and Applied, 11(1), 1-14. http://scioteca.caf.com/bitstream/handle/123456789/1091/RED2017-Eng-

8ene.pdf?sequence=12\&isAllowed=y\%oAhttp://dx.doi.org/10.1016/j.regsciurbeco .2008 .06.005\%oAhttps://www.researchgate.net/publication/305320484_SISTEM_PEMBETU NGAN_TERPUSAT_STRATEGI_MELESTARI

Andreas, K. (2010). "Users of the world, unite! The challenges and opportunities of social media." Business Horizons, 53(1), 61.

Ariyanti, A. (2020). EFL Students' Challenges towards Home Learning Policy During Covid-19 Outbreak. IJELTAL (Indonesian Journal of English Language Teaching and Applied Linguistics), 5(1), 167. https://doi.org/10.21093/ijeltal.v5i1.649 
Astia, I., \& Yunianti, S. (2020). Corpus-Based Analysis of the Most Frequent Adjective on Covid-19. Indonesian Journal of EFL and Linguistics, 5(2), 505. https://doi.org/10.21462/ijefl.v5i2.318

Atmojo, A. E. P., \& Nugroho, A. (2020). EFL Classes Must Go Online! Teaching Activities and Challenges during COVID-19 Pandemic in Indonesia. Register Journal, 13(1), 49-76. https://doi.org/10.18326/rgt.v13i1.49-76

Brown, M., Hughes, H., Keppell, M., Hard, N., \& Smith, L. (2015). Stories from Students in Their First Semester of Distance Learning. International Review of Research in Open and Distributed Learning. International Review of Research in Open and Distributed Learning, 16(4), 1-17.

Budianto, L., \& Arifani, Y. (2021). Utilizing WhatsApp-driven learning during the covid-19 outbreak: Efl users' perceptions and practices. Call-Ej, 22(1), 264-281.

Creswell, J. W. (2014). A concise introduction to mixed methods research. SAGE publications.

Culp, W. C. (2020). Coronavirus Disease 2019: In-Home Isolation Room Construction. A\&A Practice, 14(6), e01218. https://doi.org/10.1213/XAA.0000000000001218

Fauzan, \& Nadia. (2005). The Asian EFL Journal Quarterly. Asian EFL Journal, 7(4), 111-130.

Gon, S., \& Rawekar, A. (2017). Effectivity of E-Learning through Whatsapp as a TeachingLearning Tool. MVP Journal of Medical Sciences, 4(1), 19. https://doi.org/10.18311/mvpjms/o/vo/io/8454

Guy, R. (2012). the Use of Social Media for Academic Practice: a Review of Literature. Kentucky Journal of Higher Education Policy and Practice, 1(2), 7.

Hamadeh, W. (2020). Using Social Media to Enhance Second Language Learning. ComputerAssisted Language Learning Electronic Journal, 21(2), 132-149.

Hamat, A., \& Hassan, H. A. (2019). Use of social media for informal language learning by Malaysian University Students. 3L: Language, Linguistics, Literature, 25(4), 68-83. https://doi.org/10.17576/3L-2019-2504-05

Khan, I. U., Ayaz, M., \& Faheem, M. (2016). The Role of Social Media in Development of English Language Vocabulary at University Level. International Journal of Academic Research in Business and Social Sciences, 6(11), 590-604. https://doi.org/10.6007/ijarbss/v6-i11/2444

Lee, A. R., \& Bailey, D. R. (2020). Learning from experience in the midst of covid-19: Benefits, challenges, and strategies in online teaching. Call-Ej, 21(2), 176-196.

McAleer, M. (2020). Prevention is better than the cure: Risk management of COVID-19Multidisciplinary Digital Publishing Institute.

McIntosh, S. (2013). Hollowing out and the future of the labour market. BIS Research Paper, 134 .

Mendikbud. (2020). Surat Edaran Surat Edaran No. 4 Tahun 2020 tentang Pelaksanaan Kebijakan Pendidikan dalam Masa Darurat Penyebaran Corona Virus Disease (Covid19). Muhibbin Syah.(2013). Psikologi Pendidikan: Dengan Pendekatan Baru. Bandung: Remaja Rosda Karya.

Novawan, A., Aisyiyah, S., Miqawati, A. H., Wijayanti, F., \& Indrastana, N. S. (2020). The Use of Social Media in Designing The Writing Assessment for EFL Students. JER|Journal of ELT Research, 5(1), 80-93. https://doi.org/10.22236/JER

Pustika, R. (2020). Future English Teachers' Perspective towards the Implementation of ELearning in Covid-19 Pandemic Era. Journal of English Language Teaching and Linguistics, 5(3), 383. https://doi.org/10.21462/jeltl.v5i3.448 
Sari, F. M. (2020). Exploring English Learners' Engagement and Their Roles in the Online Language Course. Journal of English Language Teaching and Linguistics, 5(3), 349. https://doi.org/10.21462/jeltl.v5i3.446

Sugianto, A., \& Ulfah, N. (2020). Construing the Challenges and Opportunities of Intercultural Language Teaching Amid Covid-19 Pandemic: English Teachers' Voices. Journal of English Language Teaching and Linguistics, 5(3), 363. https://doi.org/10.21462/jeltl.v5i3.454

Traxler, J. (2018). Distance learning-Predictions and possibilities. Education Sciences, 8(1). https://doi.org/10.339o/educsci8010035

Veda, S., Issue, S., Dhanya, G., \& Veda, S. (2016). Influence of Social Media on English Language Learning. Journal of English Language and Literature, 3(1), 105-110.

Velavan, T. P., \& Meyer, C. G. (2020). The COVID-19 Epidemic. Tropical Medicine and International Health, 25(3), 278-280. https://doi.org/https://doi.org/10.1111/tmi.13383

Wang, Q., Chen, W., \& Liang, Y. (2011). The Effects of Social Media on College Students. MBA Student Scholarship, 5, 13. https://doi.org/10.1111/j.1548-1379.2010.01107.x

Wankel, C. (2009). Management education using social media. Organisation Management Journal, 6(4), 251-262. https://doi.org/10.1057/omj.2009.34

Xodabande, I. (2017). The effectiveness of social media network telegram in teaching English language pronunciation to Iranian EFL learners. Cogent Education, 4(1). https://doi.org/10.1080/2331186X.2017.1347081

Zam Zam Al Arif, T. (2019). the Use of Social Media for English Language Learning: an Exploratory Study of EFL University Students. Metathesis: Journal of English Language, Literature, and Teaching, 3(2), 224-233. https://doi.org/10.31002/metathesis.v3i2.1921 